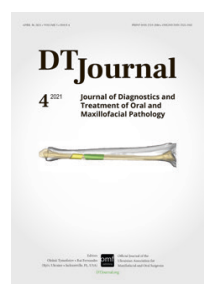

\title{
EDITORIAL
}

\section{Maxillofacial Surgery Specialization in Ukraine: A New Order and Step in the Growth of the Specialty: Analysis of Qualification Categories}

\author{
Oleksii 0. Tymofieiev ${ }^{a}$, Natalia 0. Ushkob, levgen I. Fesenko ${ }^{c, *}$, \& Olha S. Cherniak ${ }^{d}$
}

\author{
Surgeons must be very careful \\ When they take the knife! \\ Underneath their fine incisions \\ Stirs the Culprit-Life! \\ -Emily Dickinson \\ American poet
}

Oral and maxillofacial surgery (OMS) and its training systems continue to evolve around the globe. ${ }^{1}$ Review of Kumar emphasized that a wide diversity of dental/stomatology/medical background requirements and training pathways exist across the states that lead to a degree in OMS. ${ }^{1}$ Nevertheless, to our knowledge the issue of OMS education in Ukraine is not highlighted in the English-language literature. Moreover, the relevance of coverage of this issue has increased this month. As on April 23,

Kyiv, Ukraine

${ }^{a}$ Editor in Chief, dtjournal.org.

${ }^{\mathrm{b}}$ Board Member, dtjournal.org.

${ }^{c}$ Managing Editor, dtjournal.org.

d Doctor of Ultrasound Diagnostics, Head, Department of Ultrasound, Regional Diagnostic Center, Kyiv Regional Clinical Hospital.

* Corresponding author's address: OMF Publishing LLC: Journal of Diagnostics and Treatment of Oral and Maxillofacial Pathology. 13-A Simferopolska Street, Kyiv 02096, Ukraine.

E-mail: i.i.fesenko@dtjournal.org (levgen Fesenko)

ORCID: https://orcid.org/0000-0002-8901-1632

ResearchGate: $h$ ttps://researchgate.net/profile/levgen-Fesenko-3
2021 a more than a historical order for the whole oral and maxillofacial community in Ukraine was approved. ${ }^{2}$ Order \#799 of the Ministry of Healthcare of Ukraine "On Approval of Amendments to the Handbook of Qualification Characteristics of Workers' Professions. ${ }^{2}$ Issue 78 "Healthcare'”' This much-needed ministerial document orders to add a new "Maxillofacial Surgeon Doctor" (MFSD) position to the Section "Professionals in the Field of Stomatology." ${ }^{2}$

Till this Order, only a specialization in Surgical Stomatology (ie, Oral Surgery) in Ukraine exists. Despite the fact that: 1) in hospitals of every region the departments with a words "Center/ Department of Maxillofacial Surgery" in their title exist, 2) chairs of the educational institutions have the words "Maxillofacial Surgery" in their titles as

Please cite this article as: Tymofieiev OO, Ushko NO, Fesenko II, Cherniak OS. Maxillofacial surgery specialization in Ukraine: a new order and step in the growth of the specialty: analysis of qualification categories. J Diagn Treat Oral Maxillofac Pathol 2021;5(4):43-51.

Available online 30 April 2021

https://dx.doi.org/10.23999/j.dtomp.2021.4.3

(C) 2021 OMF Publishing, LLC. This is an open access article under the CC BY license (http://creativecommons.org/licenses/by-nc/4.0/). 
well, ${ }^{3}$ 3) presence of the "Maxillofacial Surgery" associations, and 4) the volume of performed types of surgery in such departments/chairs include the types of surgical interventions (head and neck infection management, facial skeleton trauma cases, removal of cysts, benign tumors, orthognathic surgery, etc.) typically performed by oral and maxillofacial surgeons abroad. Nevertheless, the management of oncologic cases was excluded from the list of the procedures allowed to be performed with a specialization in Surgical Stomatology.

The purpose of that editorial is to present the description of the Order \#799 and make brief comparison with training systems in some other 29 countries and one special administrative region.

\section{STRUCTURE OF THE MINISTERIAL ORDER \#799}

The Order includes ${ }^{2}$ :

- 23 tasks and responsibilities for the MFSDs.

- 60 clauses of what MFSDs must know and have a right to perform.

\section{TASKS AND RESPONSIBILITIES OF THE MFSD ${ }^{2}$}

1. Guided by the current legislation of Ukraine on healthcare and regulations governing the activities of government agencies and health care institutions, the organization of surgical care of the maxillofacial profile.

2. Conducts a clinical examination of the patients, determines the scope of additional research methods (laboratory, radiological, functional and others), and interprets their results.

3. Determines the severity of diseases of the maxillofacial area, identifies factors that contribute to the development of pathology.

4. Conducts differential diagnosis of diseases of the maxillofacial area that require surgical treatment.

5. Determines indications for hospitalization by disease profile, performs preoperative preparation, surgical treatment and postoperative rehabilitation of patients.

6. Establishes preliminary and clinical diagnosis in accordance with the requirements of the current version of the International Classification of Diseases.

7. Makes a treatment plan, determines the indications and contraindications to surgery, and determines the tactics of treatment.

8. Provides tertiary (highly specialized) medical care for purulent-inflammatory diseases, traumatic injuries, tumors and tumor-like lesions, congenital and acquired defects and deformities of the maxillofacial area.

9. Determines the amount of preoperative preparation taking into account age, disorders of homeostasis, nature and severity of the underlying disease and comorbidities.

10. Assesses the severity of surgical trauma in order to select an adequate method of analgesia, performs all types of local and conductive anesthesia (ie, nerve block) of the maxillofacial area, and determines the indications for various types of general anesthesia.

11. Calculates the amount of potential blood loss, determines the feasibility and methods of its correction; chooses the method of surgical intervention to perform it to the required extent. Carries out postoperative treatment of the patient.

12. Evaluates the need for participation of doctors of neighboring specialties in complex treatment.

13. Carries out preventive, diagnostic, treatment and rehabilitation measures for the following pathologies: 1) inflammatory diseases of the maxillofacial area of various etiologies, 2) specific inflammatory diseases of the maxillofacial area; 3) injuries, soft tissue injuries of the maxillofacial area and fractures of the facial skull bones of various etiologies, 4) complications arising in the treatment of diseases and injuries of the maxillofacial area, 5) congenital and acquired dysplastic lesions of the maxillofacial area; precancerous diseases and neoplasms of the maxillofacial area, 6) congenital and acquired defects and deformities of the maxillofacial area, requiring surgical treatment and rehabilitation.

14. Provides appropriate medical care in emergencies, determines its scope and sequence.

15. Organizes, conducts and participates in the examination of temporary incapacity for work of patients with injuries and other diseases of the maxillofacial area of the surgical dental profile, in cases of permanent disability directs patients to medical and social examination; 
provides emergency care to patients in terminal conditions, with group and mass lesions.

16. Supervises side effects/actions of drugs.

17. Works in close contact with neighboring specialists and services.

18. Manages the work of paramedics.

19. Adheres to the principles of medical deontology.

20. Plans medical work and analyzes its results.

21. Masters and implements in medical practice modern methods of diagnosis, treatment, rehabilitation and prevention of diseases and conditions of the maxillofacial area.

22. Maintains medical records.

23. Constantly improves own professional level.

\section{MFSD MUST KNOW}

1. Health care legislation and regulations governing the activities of government agencies and healthcare facilities.

2. Organization of maxillofacial surgical care, including ambulance and emergency in extreme situations.

3. Basics of law in medicine.

Rights, duties and responsibilities of the

4. maxillofacial surgeon doctor.

Organization of work of medical-consultative and medical-social expert commissions.

5. Etiology, pathogenesis, clinical symptoms of major surgical dental diseases, their prevention, diagnosis and principles of treatment, clinical symptoms of borderline conditions in the practice of maxillofacial surgery.

6. Indications and contraindications to emergency and urgent surgical interventions;

7. Topographic anatomy of the head and neck in adults and children.

8. Interpretation of laboratory, endoscopic, radiological results, including computed tomography (CT) (ie, multi-slice CT and cone beam CT) and magnetic resonance imaging, ultrasound methods of examination (ie, gray scale [Fig 1A], color [Fig 1B] and power

9. Doppler ultrasonography).

10. Topographic, normal and pathological anatomy, physiology.

11. General issues of biochemistry, microbiology.

12. Morphogenesis of diseases of the maxillofacial area.
13. Constants of homeostasis, water-electrolyte metabolism, the relationship of functional systems in healthy and sick.

14. General, functional and special research methods.

15. Modern classification of diseases of the oral cavity and maxillofacial area.

16. Modern methods of prevention, diagnosis and surgical treatment of dental diseases.

17. The procedure for providing medical care for surgical pathology of the maxillofacial area in adults and children.

18. The procedure for organizing the work of ambulance and emergency care for the population in case of trauma and surgical pathology of the maxillofacial area and related conditions.

19. All types of local anesthesia for various operations in the maxillofacial area.

20. Principles of preoperative preparation of patients with diseases/lesions of the maxillofacial area depending on age, presence of somatic pathology, etc.

21. Operations of typical and atypical tooth extraction (ie, impacted and semi-impacted teeth removal), cystotomy, cystectomy, periostotomy, alveoloectomy, techniques to stop bleeding after tooth extraction, techniques of tooth socket augmentation, treatment of alveolitis (ie, the dry socket management).

22. Lancing for odontogenic abscesses and phlegmons of different localization, principles of treatment of purulent lymphadenitis and adenophlegmon of the maxillofacial area and neck.

23. Surgical treatment of wounds of soft tissues of the oral cavity and maxillofacial area, the principles of their suturing, prevention of scarring and their removal.

24. Principles and methods of treatment of traumatic injuries of the maxillofacial bones, including techniques of open reposition and fixation of bone fragments (osteosynthesis), temporary/permanent immobilization of the jaw bones, methods of reposition and fixation of teeth in trauma, elimination of mandibular dislocation, the role of maxillofacial surgeon in a set of measures in the treatment of polytrauma.

25. Methods of treatment of traumatic injuries of 
the orbit, principles of correction of endocrine orbitopathy.

26. Principles of management of benign (Fig 2) and malignant neoplasms of the maxillofacial area, their differential diagnosis, types of treatment, including radiation and chemotherapy, basics of rehabilitation of cancer patients.

27. Biopsy methods.

28. Methods of preparation of the oral cavity for orthopedic treatment, bone-plastic and soft tissue operations before dental implantation.

29. Methods of dental implantation (eg, application of traditional root-form dental implants [ie, jaw implants] and zygomatic implants [also known as "zygoma implants"]).

30. Principles and methods of treatment of congenital, in particular cleft lip and palate, and acquired defects and deformities of the maxillofacial area.

31. Principles and methods of orthognathic surgery (ie, bilateral sagittal split osteotomy, Le Fort I osteotomy, genioplasty, etc.) and distraction osteogenesis.

32. Surgical correction of disorders of proportionality and symmetry of the face.

33. Methods of treatment of degenerative, inflammatory and dystrophic diseases of the temporomandibular joint.

34. Methods of surgical treatment of diseases of the salivary glands, including parotidectomy with preservation of the branches of the facial nerve.

35. Methods of tissue transplantation from distant parts of the body, both free and with the restoration of blood supply.

36. Principles and methods of bone transplantation in the maxillofacial area, types of transplants (ie, grafts).

37. The use of alloplastic materials in maxillofacial surgery, in particular craniofacial implants.

38. Restorative operations of the upper, middle and lower areas of the face using osteomyocutaneous flaps (eg, fibula free flap, etc).

39. Restoration of the auricles with partial or complete defects.

40. Restorative operations on the upper and lower eyelids using local tissues.

41. Restoration of the nose with complete and partial defects, operations on changing the shape of the nose.

42. The principles of ectoprosthetics (ie, application of ectoprostheses).

43. Methods of surgical treatment of paresis and paralysis of the facial nerve.

44. General surgical and specific complications during operations in the maxillofacial area.

45. Volume and sequence of resuscitation measures for complex and combined injuries of the maxillofacial area.

46. Methods of cardiopulmonary resuscitation and principles of treatment of emergencies (sudden cessation of blood circulation, acute respiratory failure, allergic and comatose states, hypothermia, drowning, electric shock).

47. Methods of rehabilitation of patients after surgery in the craniofacial area.

48. Features of emergency care by doctors of neighboring specialties.

49. Prevention and treatment of shock.

50. Methods of anesthesia, intensive care and resuscitation.

51. Issues of providing medical care to patients with benign and malignant neoplasms, in particular the principles of radiation and chemotherapy.

52. Basics of pharmacotherapy and immunology.

53. Clinical course of specific and general complications, methods of their prevention and treatment.

54. Methods of physiotherapy and dietary nutrition in maxillofacial surgery.

55 . Rules of safety and hygiene in the operating room, organization of work and equipment of the department of maxillofacial surgery.

56. Rules of asepsis and antiseptics, forms and methods of sanitary education.

57. Rules of registration of medical documentation.

58. Basics of labor legislation.

59. Rules of labor protection and fire safety.

60. Sanitary rules and norms of functioning of the medical organization, modern literature on a specialty and methods of its analysis.

\section{THREE QUALIFICATION CATEGORIES}

The order \#799 is including clear rules (Table 1) about possibility to obtain gradually one of the three different categories (second, first, and highest) for MFSDs depending on education, internship, availability of the corresponding certificate, continuing professional development (CPD), and the years of professional experience. ${ }^{2}$ 

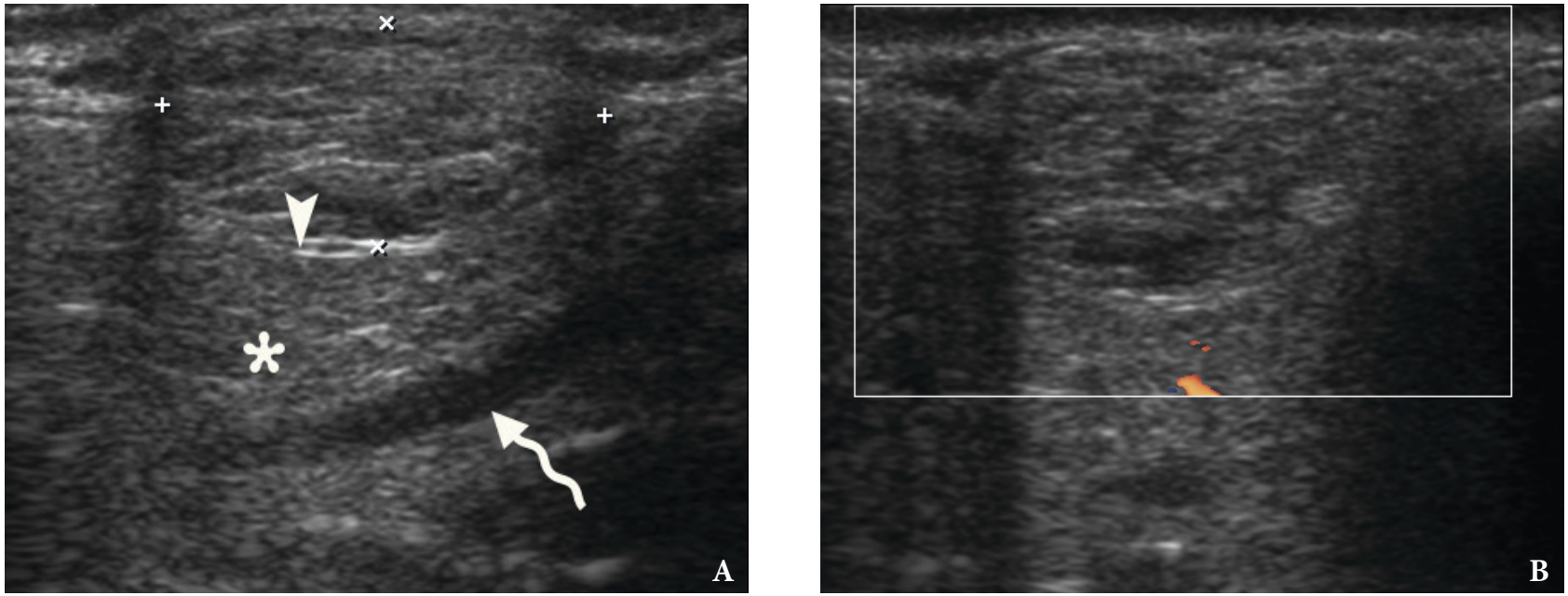

FIGURE 1. Case 1. Gray scale (A) and color Doppler (B) ultrasound (US) examination helps to distinguish parotid gland tumor mimickers. In that case, the lipoma (its margins are indicated by ' + ' and ' $x$ ' calipers) measured $2.04 \times 1.03 \mathrm{~cm}$ was tightly adjacent to the outer surface of the parotid fascia (arrowhead) and color Doppler US proved its avascular structure. Parotid gland is labeled by asterisk and the retromandibular vein by arrow. Printed with permission and copyrights retained by 0.S.C.

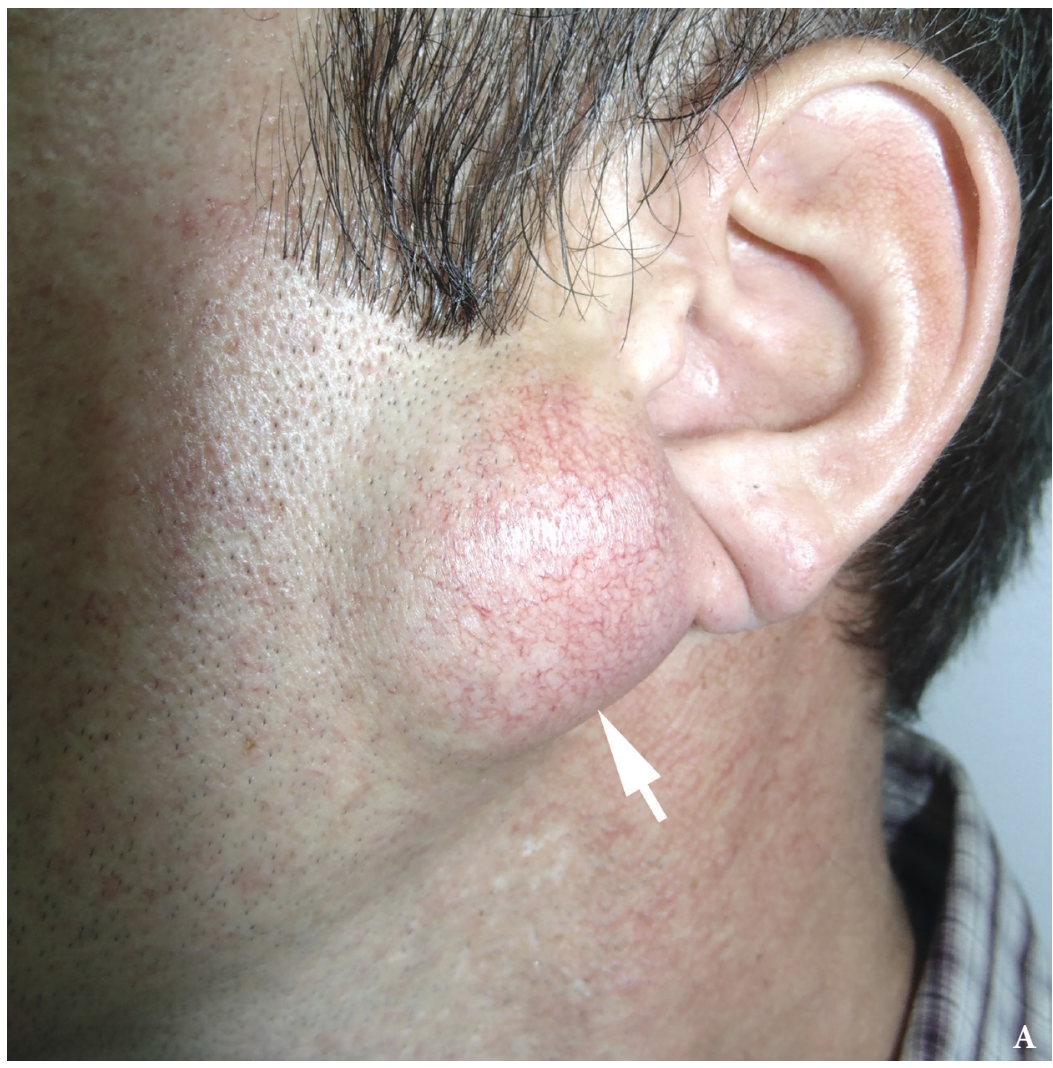

FIGURE 2. Case 2. Left lateral view (A) of a 42-year-old male with parotid gland tumor mimicker (arrow). Gray scale (ie, B-mode) US (B) shows round shape hypoechoic lesions with heterogenic content (asterisk) and smooth borders (arrowheads) neighboring with outer surface of parotid fascia. Lesion `s avascular structure presented on the color Doppler US (C). Image D shows a specimen, cystic wall (arrow) and cheesy-smelled content (arrowheads) of which

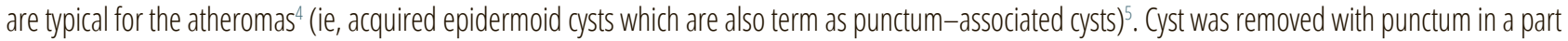
of skin (curved arrow). Images $\mathbf{A}$ and $\mathbf{D}$ printed with permission and copyrights retained by I.I.F. Images $\mathbf{B}$ and $\mathbf{C}$ printed with permission and copyrights retained by retained by 0.S.C. (Fig 2 continued on next page.) 

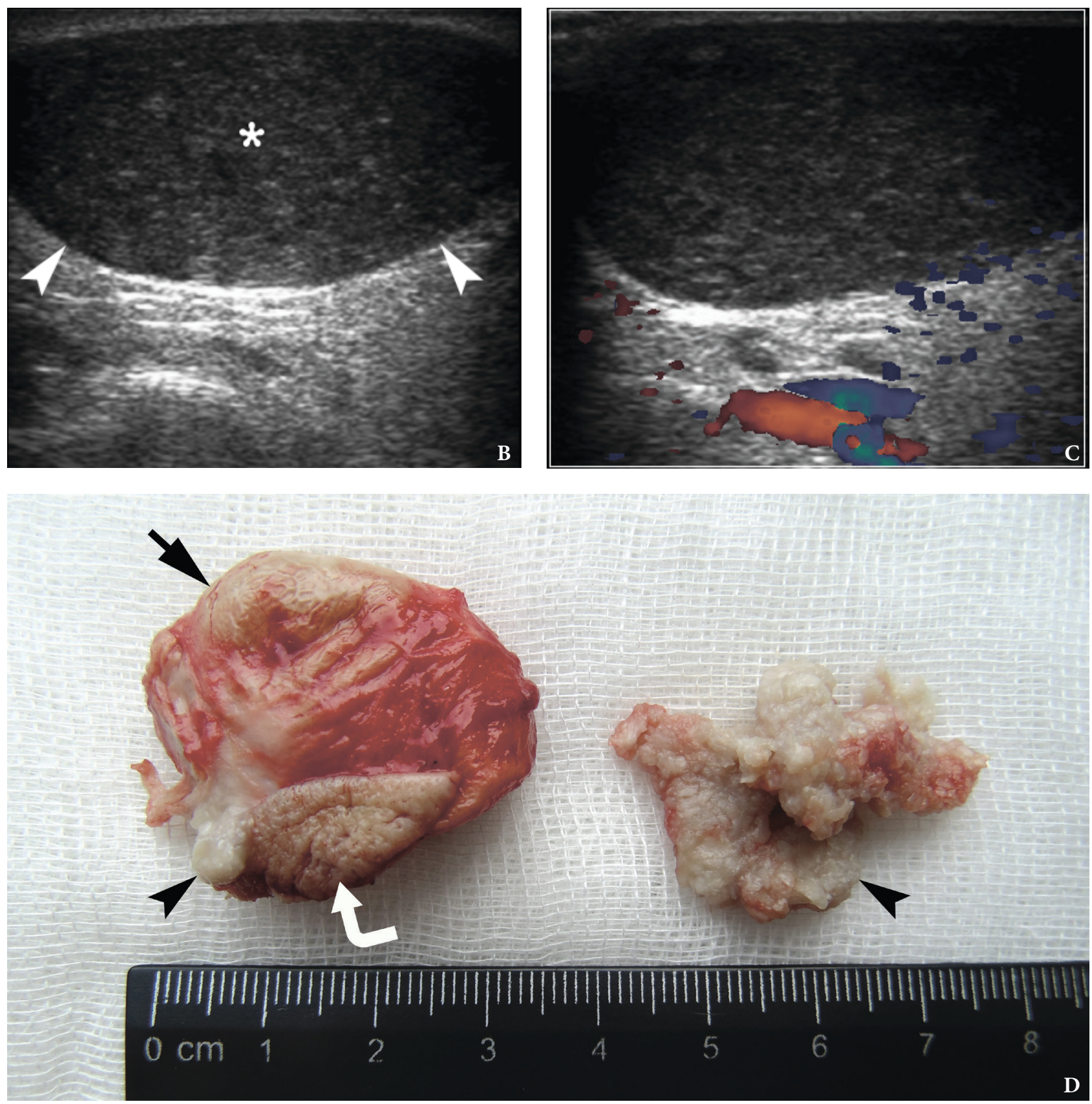

FIGURE 2 (continued). Case 2. Left lateral view (A) of a 42-year-old male with parotid gland tumor mimicker (arrow). Gray scale (ie, B-mode) US (B) shows round shape hypoechoic lesions with heterogenic content (asterisk) and smooth borders (arrowheads) neighboring with outer surface of parotid fascia. Lesion `s avascular structure presented on the color Doppler US (C). Image D shows a specimen, cystic wall (arrow) and cheesy-smelled content (arrowheads) of which are typical for the atheromas ${ }^{4}$ (ie, acquired epidermoid cysts which are also term as punctum-associated cysts) $)^{5}$. Cyst was removed with punctum in a part of skin (curved arrow). Images $\mathbf{A}$ and $\mathbf{D}$ printed with permission and copyrights retained by l.I.F. Images $\mathbf{B}$ and $\mathbf{C}$ printed with permission and copyrights retained by retained by 0.S.C. 
TABLE 1. Qualification Requirements.

\begin{tabular}{|c|c|c|c|c|c|}
\hline $\begin{array}{c}\text { Qualification } \\
\text { Category }\end{array}$ & $\begin{array}{l}\text { Higher Education of the } \\
\text { Second (Master's) Level } \\
\text { in the Field of Knowledge } \\
22 \text { "Healthcare" in the } \\
\text { Specialty "Stomatology" }\end{array}$ & $\begin{array}{c}\text { Internship in } \\
\text { "Stomatology" with } \\
\text { Further Specialization } \\
\text { in "Maxillofacial } \\
\text { Surgery" }\end{array}$ & Certificates & $\begin{array}{l}\text { Continuing } \\
\text { Professional } \\
\text { Development } \\
\text { (CPD) }\end{array}$ & $\begin{array}{c}\text { Professional } \\
\text { Experience, yrs }\end{array}$ \\
\hline $\begin{array}{l}\text { Maxillofacial } \\
\text { Surgeon Doctor } \\
\text { of the Highest } \\
\text { Qualification } \\
\text { Category }\end{array}$ & Required & Required & $\begin{array}{l}\text { Certificate of a } \\
\text { doctor specialist } \\
\text { and a certificate } \\
\text { of assignment } \\
\text { (confirmation) of the } \\
\text { Highest qualification } \\
\text { category in this } \\
\text { specialty }\end{array}$ & Mandatory & More than $10 \mathrm{yrs}$ \\
\hline $\begin{array}{l}\text { Maxillofacial } \\
\text { Surgeon Doctor } \\
\text { of the First } \\
\text { Qualification } \\
\text { Category }\end{array}$ & Required & Required & $\begin{array}{l}\text { Certificate of a } \\
\text { doctor specialist } \\
\text { and a certificate } \\
\text { of assignment } \\
\text { (confirmation) of the } \\
\text { First qualification } \\
\text { category in this } \\
\text { specialty }\end{array}$ & Mandatory & More than $7 \mathrm{yrs}$ \\
\hline $\begin{array}{l}\text { Maxillofacial } \\
\text { Surgeon Doctor } \\
\text { of the Second } \\
\text { Qualification } \\
\text { Category }\end{array}$ & Required & Required & $\begin{array}{l}\text { Certificate of a } \\
\text { doctor specialist } \\
\text { and a certificate } \\
\text { of assignment } \\
\text { (confirmation) of the } \\
\text { Second qualification } \\
\text { category in this } \\
\text { specialty }\end{array}$ & Mandatory & More than $5 \mathrm{yrs}$ \\
\hline $\begin{array}{l}\text { Maxillofacial } \\
\text { Surgeon Doctor }\end{array}$ & Required & Required & $\begin{array}{l}\text { Certificate of a doctor } \\
\text { specialist }\end{array}$ & Not required & $\begin{array}{l}\text { Without work } \\
\text { experience } \\
\text { requirements }\end{array}$ \\
\hline
\end{tabular}

\section{DISCUSSION}

Being more than a 44 million population country, Ukraine during the first 30 years of independence till the order \#799 have only the Surgical Stomatology (ie, Oral Surgery) specialization for doctors with stomatological degree who want to perform the jaws-head-neck surgeries typically performed by oral and maxillofacial surgeons in countries like United States, Canada, France, Greece, etc.

During the first years of independence the doctors with medical degree also have a permission to obtain specialization in Surgical Dentistry and to work in maxillofacial surgery departments. But the further reforms declined the possibility for doctors with medical degree to obtain such specialization.

The new Ukrainian Maxillofacial Surgery legislation, education and training system requires only a stomatological degree. Laskin classified four basic educational requirements for training in OMS. ${ }^{6}$ Analysis of the required educational degrees for OMS training in 29 countries and one special administrative region revealed seven different forms of the required education (Table 2). Thus, the fact that Ukrainian OMS legislation system requires stomatological degree to obtain Maxillofacial Surgery specialization makes it similar to Chile and China educational systems in that particular aspect. ${ }^{6,7}$ 
TABLE 2. Required Education Degree for the Possibility to be Trained in "Oral and Maxillofacial Surgery," "Stomatology and Maxillofacial Surgery" or "Maxillofacial Surgery.",2 The Kumar's ${ }^{1}$ and Laskin's ${ }^{6}$ Data are Supplemented by the Information from Ukrainian Order \#799.

\begin{tabular}{|c|c|c|c|}
\hline & \multicolumn{2}{|r|}{ Required Education } & Countries \\
\hline \multirow{4}{*}{1} & \multirow{4}{*}{$\begin{array}{l}\text { Dental } \\
\text { education } \\
\text { only }\end{array}$} & $\begin{array}{l}\text { No mandatory requirements for obtaining a } \mathrm{PhD} / \\
\text { Master of Science upon the OMS training period }\end{array}$ & $\begin{array}{l}\text { Denmark, Hong Kong (a special administrative } \\
\text { region, China), }{ }^{1} \text { Iceland, }{ }^{8} \text { India, Malaysia, }{ }^{1} \text { the } \\
\text { Netherlands, Spain, }{ }^{1} \text { Sweden, Turkey }{ }^{1}\end{array}$ \\
\hline & & + obtaining a PhD upon the OMS training period ${ }^{6}$ & Korea, Japan \\
\hline & & $\begin{array}{l}\text { + obtaining a PhD or Master of Science degree upon } \\
\text { the OMS training period }\end{array}$ & Taiwan \\
\hline & & $\begin{array}{l}\text { + obtaining a Master of Science degree upon the OMS } \\
\text { training period }^{6}\end{array}$ & Singapore \\
\hline 2 & \multicolumn{2}{|c|}{ Stomatological education only } & Chile $^{7}$, China, Ukraine \\
\hline 3 & \multicolumn{2}{|c|}{ Medical education only } & France \\
\hline 4 & \multicolumn{2}{|c|}{ 1) Dental or 2) medical education } & Italy, Portugal \\
\hline 5 & \multicolumn{2}{|c|}{ Combination of dental and medical education } & Austria, Belgium \\
\hline 6 & \multicolumn{2}{|c|}{$\begin{array}{l}\text { Combination of dental and medical education and a year in general } \\
\text { surgery }^{9}\end{array}$} & Australia \\
\hline 7 & \multicolumn{2}{|c|}{ 1) Combination of dental and medical education or 2) only dental degree } & $\begin{array}{l}\text { Canada, Finland, Germany, Greece, Hungary, } \\
\text { Switzerland, the United Kingdom, the United States }\end{array}$ \\
\hline
\end{tabular}

Summarizing 60 clauses describing what MFSDs in Ukraine must know, the clauses \#9, 29, 31, 38 and 42 are more than worth of attention. ${ }^{2}$

From the clause \#9, a special interest has interpretation of ultrasonography. As being a dynamic method of examination, ultrasound begins to occupy an increasingly important place in the practice of oral and maxillofacial surgeons. ${ }^{10-12}$

The clauses \#29 and 42 attract the attention due to the improvements of the zygomatic implants techniques ${ }^{13-15}$ and application of the ectoprostheses ${ }^{14}$.

Nowadays, the clauses \#31 and 38 are more than important because the implementation of the orthognathic surgery ${ }^{16-18}$ and osteomyocutaneous flap ${ }^{19,20}$ surgeries with a lot of new techniques and principles into the university hospitals and private practices continues to grow around the world.

Summing up the Discussion chapter, it's worth to mention the statement of Sales and Sales who emphasized that till November 2020 there was no consensus what is the best form of education for training process in OMS. ${ }^{21}$

\section{CONCLUSIONS}

In sum, at the end of April 2021 in Ukraine are existing two specializations related with oral and maxillofacial surgery - "Surgical Stomatology" and new newly launched "Maxillofacial Surgery." Both specialties accept only a stomatological background. According to the new ministerial order maxillofacial surgeons doctors have well described 1) 23 tasks and responsibilities and 2) 60 clauses of what maxillofacial surgeons doctors must know. All of them are important, but some of them, like osteomyocutaneous flap surgeries more than others corresponds to the spirit of time and patients' needs.

All future training aspects in residency in "Maxillofacial Surgery" in Ukraine need a profound analysis and a comparison with OMS training period in residency in other countries.

\section{ROLE OF CO-AUTHORS}

Conceptualization: Tymofieiev OO, Ushko NO, Fesenko II. Data and interpretation acquisition: Fesenko II, Cherniak OS. Drafting of the manuscript: Fesenko II. Critical revision of the manuscript: Tymofieiev OO, Ushko NO, Fesenko II, Cherniak OS. Approval of the final version of the manuscript: all authors.

\section{REFERENCES}

1. Kumar S. Training pathways in oral and maxillofacial surgery across the globe - a mini review. J Maxillofac 
Oral Surg 2017;16(3):269-76.

https://doi.org/10.1007/s12663-017-1020-0

2. Order of the Ministry of Healthcare of Ukraine dated 23.04.2021 \# 799 "On approval of amendments to the handbook of qualification characteristics of workers' professions. Issue 78 "Healthcare"' [document on the internet]; April 23, 2021 [cited 2021 Apr 25]. Available from:

https://moz.gov.ua/article/ministry-mandates/ nakaz-moz-ukraini-vid-23042021--799-prozatverdzhennja-zmin-do-dovidnika-kvalifikacijnihharakteristik-profesij-pracivnikiv-vipusk-78ohorona-zdorov\%e2\%80\%99ja

3. Tymofieiev OO. Manual of maxillofacial and oral surgery [Russian]. 5th ed. Kyiv: Chervona Ruta-Turs; 2012.

4. Tymofieiev OO. Maxillofacial surgery and surgical dentistry [Russian]. Kyiv, Ukraine: Medicine; 2020.

5. Fesenko II, Snisarevskyi PP, Zaritska VI. Infected punctum-associated cyst mimicking erysipelas. $J$ Diagn Treat Oral Maxillofac Pathol 2021;5(2):15-9. https://doi.org/10.23999/j.dtomp.2021.2.1

6. Laskin DM. The past, present, and future of oral and maxillofacial surgery. J Oral Maxillofac Surg 2008;66(5):1037-40. https://doi.org/10.1016/j.joms.2007.11.037

7. Cartes-Velásquez R, Ramírez Skinner H. Dual-degree oral and maxillofacial surgery [in Spanish]. Int J Odontostomat 2011;5(2):191-8. https://doi.org/10.4067/S0718-381X2011000200013

8. Fiehn N-E. Perspectives on dental education in the Nordic countries. J Dent Educ 2002;66(12):1374-80. https://doi.org/10.1002/j.0022-0337.2002.66.12. tb03611.x

9. Faculty of health and medical sciences: oral and maxillofacial surgery: application procedures [document on the internet]; April 14, 2021 [cited 2021 Apr 14]. Available from:

https://health.adelaide.edu.au/study-with-us/ dentistry-oral-health/oral-maxillofacial-surgery

10. Ryba FM, George K. Point-of-care ultrasound for oral and maxillofacial surgeons. Br J Oral Maxillofac Surg 2017;55(6):600-3.

https://doi.org/10.1016/j.bjoms.2017.03.015

11. Costa, SM, Lanes Silveira R., Amaral, MBF. Ultrasonography on the early postoperative control of severe odontogenic infections. J Oral Maxillofacial Surg 2020;79(3):608-10.

https://doi.org/10.1016/j.joms.2020.09.010
12. Mitchell OR, Couzins M, Dave R, Bekker J, Brennan PA. COVID-19 vaccination and low cervical lymphadenopathy in the two week neck lump clinic - a follow up audit. Br J Oral Maxillofac Surg 2021;59: article in press.

https://doi.org/10.1016/j.bjoms.2021.04.008

13. Weyh AM, Nocella R, Salman SO. Commentary step-by-step: zygomatic implants. J Oral Maxillofac Surg 2020;78(4):e6-e9.

https://doi.org/10.1016/j.joms.2020.01.024

14. Le JM, Chen PH, Seidenfaden JC, Morlandt AB, Kase MT. Zygomatic implants for restoration of complex nasal defects - a case report and outcome. J Diagn Treat Oral Maxillofac Pathol 2020;4(9):152-61. https://doi.org/10.23999/j.dtomp.2020.9.2

15. Chow J. Zygomatic implants. Cham, Switzerland: Springer International Publishing; 2020.

https://doi.org/10.1007/978-3-030-29264-5

16. Claus JDP, Almeida MS, Zille D. Customization in minimally invasive orthognathic surgery. Adv Oral Maxillofac Surg 2021;3:100114. https://doi.org/10.1016/j.adoms.2021.100114

17. Denson DA, Waite PD, Digumarthi H, Everts JE. Orthognathic surgery: a comparison of academic vs. private practice. J Oral Maxillofac Surg 2015;73(9):Suppl.e63. https://doi.org/10.1016/j.joms.2015.06.144

18. Naran S, Steinbacher DM, Taylor JA. Current concepts in orthognathic surgery. Plast Reconstr Surg 2018; 141(6):925e-936e. https://doi.org/10.1097/PRS.0000000000004438

19. Hanna TC, Kraus DH. State of the art simultaneous bilateral segmental mandibular reconstruction using a single fibula transplant: discussion of the surgical steps. J Diagn Treat Oral Maxillofac Pathol 2019;3(3):76-103. https://doi.org/10.23999/j.dtomp.2019.3.2

20. Bolzoni AR, Baj A, Sweed AH, Giannì AB, Montrasio EF, Beltramini GA. Role of axial split osteotomy of free fibula flap in mandibular reconstruction and dental rehabilitation. Plast Reconstr Surg Glob Open 2020;8(1):e2546. https://doi.org/10.1097/GOX.0000000000002546

21. Sales PHDH, Sales PLG. Dental, medical or double degree? Is there an ideal educational formation to oral and maxillofacial surgeons around the world? J Stomatol Oral Maxillofac Surg 2021:S24687855(21)00041-0.

https://doi.org/10.1016/j.jormas.2021.02.002 